\begin{abstract}
Recent research has encouraged the study of psychological empowerment in public organizations owing to its benefits for optimum service delivery and performance improvement in the public context. This study analyzes how learning goal orientation, proveperformance goal orientation, and avoid-performance goal orientation are related to psychological empowerment and how such empowerment influences well-being outcomes within the context of public employees. Analyses of data from 553 public-sector employees showed that only learning goal orientation strongly and positively influences psychological empowerment. Furthermore, the results support the positive and significant relationship between psychological empowerment and both job satisfaction and affective commitment, and the negative link with job anxiety levels. Theoretical and practical implications, as well as future directions for the psychological empowerment issue, are discussed.
\end{abstract}




\section{Psychological Empowerment: Antecedents from Goal Orientation and Consequences in}

\section{Public Sector Employees}

Public employee management has taken more notice of the role the workforce plays in improving performance (Feeney \& DeHart-Davis, 2009; Nicholson-Crotty, Nicholson-Crotty, \& Fernandez, 2017), which is the aim of many recent public sector performance-based reforms (Hall, 2017; Onesti, Angiola, \& Bianchi, 2016; Van Dooren, Bouckaert, \& Halligan, 2010) undergirded by the New Public Management (NPM) approach (Ter Bogt, Van Helden, \& Van Der Kolk, 2015). In this context, employees need to take risks, be more creative and proactive, and find ways to improve the services they provide and their performance in general (Diefenbach, 2009; Pitts, 2005). Psychological empowerment is an important factor (Brunetto et al., 2012; Scotti, Harmon, \& Behson, 2007) in this environment as it entails a combination of individuals' psychological states related to feelings of control at work (Spreitzer, 1995). Since psychological empowerment implies a feeling of awareness of the work context, accountability for personal work output, and, overall, a powerful state of mind (Gautam \& Ghimire, 2017; George \& Zakkariya, 2014), it may prove highly beneficial for optimum service delivery and improving performance in the public context (Van Loon, 2017; Taylor, 2013).

Although some studies have noted the value of the psychological approach to further understanding of how it directly influences public employees' attitudes (e.g., Fernandez, Resh, Moldogaziev, \& Oberfield, 2015), it has not been widely considered in the literature. NPM and performance management literature in general have examined management practices as a way to increase citizens' satisfaction and performance, but have devoted very little attention to employees' perceptions and experiences (Steijn, 2004). Numerous questions therefore remain unanswered on the consequences and antecedents of psychological empowerment, both in public contexts and research in general (Maynard, Gilson, \& Mathieu, 
2012). It is particularly important to understand which factors foster employees' feelings of empowerment and their consequences in greater depth (Macsinga, Sulea, Sârbescu, Fischmann, \& Dumitru, 2015; Seibert, Wang, \& Courtright, 2011).

With regard to antecedents, individual dispositions and orientations-such as goal orientation (GO) (e.g., Dweck, 1986) — may affect feelings of psychological empowerment, although as Maynard et al. (2012) highlight, they have rarely been addressed. GO in the demanding public sector context is important to examine, because it increases the motivational force that could condition how employees strive to meet targets in goal-setting contexts such as NPM and performance-based reforms (Taylor, 2013). Employees' GO might shape their psychological empowerment because it helps to explain their motivations to succeed or to avoid failure, their work behaviors, interests, interpretations, and receptiveness to professional development activities (Barrick, Mount, \& Li, 2013; Joo, Park, \& Lim, 2016; VandeWalle, 1997). Hence, as a motivational factor, GO may condition the feeling of control employees perceive they have over their work; that is, their psychological empowerment.

As for the consequences, within the context of NPM and more recent performancebased reforms, employees' satisfaction and commitment have been shown to achieve success in public organizations (Gomes, Mendes, \& Carvalho, 2017; Hansen \& Høst, 2012; Park \& Rainey, 2007; Perry, 2004), and the way psychological empowerment can foster this satisfaction and commitment calls for further analysis. Moreover, psychological empowerment may be expected to help employees to cope with job anxiety, which is a significant problem in the public sector (Jarman et al., 2014; Wieclaw et al., 2008).

In this context, our purpose in this research is to explore the relationship between GO and psychological empowerment, and between psychological empowerment and three employee well-being outcomes: job satisfaction, affective commitment, and job anxiety. To 
this end, we design an empirical study using a sample of 553 Spanish city council employees and apply structural equation modeling (SEM) to test the proposed relationships.

This article contributes to understanding of psychological empowerment in three main ways. First, we expand on the individual dispositions that lead to psychological empowerment by studying GO as its antecedent, which is a relatively innovative approach in the literature. As far as we know, only one empirical study (Joo et al., 2016) has addressed the relationship between GO and psychological empowerment, although their study was carried out in the private sector and focused on only one of its dimensions (learning goal orientation). Furthermore, given the distinctive characteristics of public employees - they generally have permanent job tenure, for example (Barba \& Serrano, 2015)—one very interesting area of public management practice to examine is the importance of the role that GO could play in their psychological state and, hence, in their well-being outcomes, which can in turn influence general public sector results.

Second, we expand knowledge about the consequences of psychological empowerment on several well-being variables (Maynard, Luciano, D'Innocenzo, Mathieu, \& Dean, 2014). We consider that job satisfaction and affective commitment represent eudaimonic well-being related to the self-realization component, and that job anxiety is a health outcome and hedonic well-being variable related to attaining pleasure and avoiding pain (Ryan \& Deci, 2001). We test these variables on a sample of public employees. Thus, we add to the empirical evidence on health outcomes (hedonic type), which is of interest in that hedonic well-being differs from other types (Van De Voorde, Paauwe, \& Van Veldhoven, 2012).

Finally, we extend research on psychological empowerment by examining it in a novel public sector context: Spanish local authorities. Previous contributions on psychological empowerment in the public sector have mainly explored the nursing context 
(e.g., Chang \& Liu, 2008; Smith, Andrusyszyn, \& Laschinger, 2010), while studies of the Spanish public sector have generally focused on management issues (e.g., Barba \& Serrano, 2015; Torres, Pina, \& Yetano, 2011) and have neglected the employee's viewpoint. It is important to examine how psychological empowerment can be achieved, and analyze its effects in previously unexplored contexts, given that differences across contexts can have notable implications for relationships involving empowerment (Joo et al., 2016; Kim, Lee, \& Jang, 2017; Macsinga et al., 2015; Maynard et al., 2012; Petter, Byrnes, Choi, Fegan, \& Miller, 2002). Since this approach helps to generalize psychological empowerment models, according to Whetten (1989), it can be considered a significant step forward in theoretical development.

The next section provides a review of the literature that justifies the relationships proposed. The data and methods are then explained, followed by the results of the analyses. Finally, the implications, limitations, and main conclusions are discussed.

\section{THEORETICAL BACKGROUND AND HYPOTHESES}

The research model is presented in Figure 1. In our article, we adopt Spreitzer's (1995) notion of psychological empowerment. Following Thomas and Velthouse's (1990) conceptualization, Spreitzer's model (1995, p. 1444) describes psychological empowerment "as a motivational construct manifested in four cognitions: meaning, competence, selfdetermination, and impact". Meaning refers to the importance an individual attaches to the job, according to his or her own values. Competence refers to the extent to which a person believes they can perform activities proficiently when they try. Self-determination or autonomy is the sense that one has a choice in when to start and how to perform actions. Finally, impact refers to individuals' perception of the influence they have on outcomes at work (Spreitzer, 1995; Thomas \& Velthouse, 1990). 


\section{The Spanish context}

Spain has applied NPM principles, such as performance measurement, more slowly and less intensely (Garcia, 2007) than other countries. In fact, the reforms implemented can be considered as a succession of readjustments, rather than real changes, in response to the public's perception of the public administration as bureaucratic and inefficient, and to external pressures to improve public services in Spain (Torres et al., 2011).

Regardless of the causes, as Balaguer (2004) notes, there is an increasing concern to improve managers' professional skills and introduce measures that will enhance quality in these services. Attempts have therefore been made to professionalize human factor management in the Spanish administration (Cuenca, 2010), and all the proposed reforms have advocated applying modern techniques to manage the public sector workforce. In this same line, some legal mandates have been introduced, such as the Basic Statute of Public Employment (Estatuto Básico del Empleado Público - EBEP, 2007), which provides the frame for local administration HRM policies. It is aimed to seek the most qualified people for each job (Barragán \& Pérez, 2012). Nevertheless, the predominant civil servant profile and the general structural rigidity of the public administration system hinder the implementation of participation, competition, and performance-based reforms (Serna, 2008; Torres et al.,

2011). Furthermore, the economic crisis has resulted in a freeze on recruitment of new employees and significant reductions in local government staff in recent years (Statistical Gazette of the Staff at the Service of Public Administrations - Boletín estadístico del personal al servicio de las Administraciones Públicas, July 2016), with the subsequent aging of the workforce.

\section{Goal Orientation as an Antecedent of Psychological Empowerment}


Goal orientation theory (Pintrich, 2000; VandeWalle, 1997) seeks to discover what leads people to respond differently to achievement settings (Rusk \& Rothbaum, 2010). Its most recent conception (e.g., VandeWalle, 1997, p. 995) understands goal orientation as "an individual disposition toward developing or validating one's ability in achievement settings," which is shaped by three different factors: Learning goal orientation (LGO) is the goal orientation directed toward enhancing competence by mastering new abilities and situations (Dweck, 1986); Prove-performance goal orientation (PPGO) is the aspiration to prove one's competence and to obtain positive appraisals for it (VandeWalle, 1997), with an inherent motivation to compete against others (Dietz et al., 2015); and Avoid-performance goal orientation (APGO) refers to the desire to avoid disproval of and negative judgments about one's competence (VandeWalle, 1997).

Learning Goal Orientation. Many studies have demonstrated significant associations between LGO and feelings of competence (e.g., Cellar et al., 2011; Payne, Youngcourt, \& Beaubien, 2007; Phan, 2009). Competence is included in the conceptualization of psychological empowerment, referring to the confidence in one's own ability to do the job. When they have a LGO, individuals approach tasks with the intention of developing their skills, competency, and mastery through additional effort (Dweck \& Legget, 1988; Lee, Tinsley, \& Bobko, 2003). These characteristics are congruent with senses of psychological empowerment (To, Fisher, \& Ashkanasy, 2015). Given that psychological empowerment involves feeling control over work and performing activities skillfully, it can be more easily achieved when employees are willing to learn. People with high LGO are more likely to have positive affect, which means they feel more satisfied with training activities (Brown, 2005). In the public sector, where NPM and the recent performance-based reforms require public employees to meet high expectations (Hall, 2017) and learn and master new tasks in order to improve the services they provide, their levels of LGO could play a pivotal role in their 
feelings of empowerment. The only empirical study to date that has tested the relationship between LGO and psychological empowerment (Joo et al., 2016) confirmed these ideas, finding a positive relationship for a sample of employees from consulting firms in Korea.

In Spain, Article 1 of the Basic Statute of the Public Employee-Estatuto Básico del Empleado Público (EBEP, 2007)—refers to issues such as continuous professional development and qualification of public employees as the basis for new public personnel policies. The aim of this legislation is to stimulate employees to carry out their responsibilities efficiently and provide them with suitable training, and it specifically provides for public employee training programs. Additionally, because civil servants typically enjoy long-term job security (Torres et al., 2011), they are more likely to approach learning activities with a confident state of mind, which allows them to take full advantage of the learning situation. Individuals with a LGO disposition will therefore be more likely to feel they have an influence on the work they do, and to perceive meaningfulness, or capability. The following hypothesis is therefore put forward:

Hypothesis 1a. There is a positive relationship between LGO and psychological empowerment.

Prove-Performance Goal Orientation. According to the most recent perspective- the revised goal theory (Pintrich, 2000)—performance goals could be useful in that they provide an external reference with which to evaluate performance and interpret feedback (Butler \& Winne, 1995). In fact, some empirical research has associated these goals with positive achievement outcomes (e.g., Harackiewicz, Barron, Tauer, Carter, \& Elliot, 2000), such as task value, self-efficacy, and the use of cognitive and metacognitive strategies (Wolters, $\mathrm{Yu}$, \& Pintrich, 1996).

Elliot and Harackiewicz (1996) state that PPGO, as in the case of LGO, represents an approach orientation grounded in self-regulation conditioned by potential positive results, 
such as task mastery, which encourages immersion in the task. In this vein, several studies (e.g., Cellar et al., 2011; Elliot \& Moller, 2003) have found positive links between PPGO and feelings of competence. In the public context, some techniques such as performance evaluation are being implemented in response to the challenge to improve human resource management proposed in the latest reforms (Barba \& Serrano, 2015). High-PPGO employees could be motivated by this new situation, since their individual performance and comparisons with colleagues may come to light, so they may demonstrate and be rewarded for their performance, thus raising their levels of psychological empowerment.

Moreover, PPGO can be functional or not, depending on the task (Noordzij, Van Hooft, Van Mierlo, Van Dam, \& Born, 2013), so that when tasks are routine and easy, PPGO is functional (Sanusi, Iskandar, \& Poon, 2007; Winters \& Latham, 1996). In the Spanish local government context, tasks are typically routine and well-established (Hall, 2017), and are carried out by employees with long tenure in their organizations, which means they are generally familiar with their tasks. Employees with a PPGO disposition may therefore be more likely to experience feelings of competency or impact regarding their work.

On the other hand, PPGO has been shown to be bolstered by both achievement motivation and the fear of failure (Elliot \& Church, 1997). Middleton, Kaplan and Midgley (2004) propose that the weight of each of these dispositions in the PPGO is related to the level of opportunity for success in the particular environment. In the context of Spanish local governments, employees' permanent tenure (Barba \& Serrano, 2015) together with reinforcement from the training programs embedded in performance-based reforms such as the EBEP, could lead them to perceive that they have considerable opportunities to gain benefits, without considering the negative consequences if they fail, because of their substantial job security. This may be also be reinforced by the influence public sector trade unions have on Spanish local governments (Torres et al., 2011), which could enhance 
feelings of security. In light of the above studies, the specific context analyzed here, and the revised perspective on goal theory, we hypothesize that:

Hypothesis $1 b$. There is a positive relationship between PPGO and psychological empowerment.

Avoid-Performance Goal Orientation. As Chadwick and Raver (2015) note, the literature points to a strong association between APGO and negative outcomes. From both the traditional and the more recent perspectives of GO theory (Pintrich, 2000), this performance goal is conceptualized as an avoidance orientation based on self-regulation conditioned by possible negative outcomes (Elliot \& Harackiewicz, 1996). These authors claim that an APGP engenders a process that complicates optimal task engagement. Hence, feelings of psychological empowerment are probably lower among individuals with a high APGO, since its related mechanisms will be unlikely to foster, for instance, feelings of competence or meaning in an employee. Previous empirical research (e.g., Elliot \& Church, 1997; Elliot \& Harackiewicz, 1996; Pintrich, 2000) supports this view, finding APGO to be negatively related to the interest in an activity for its own sake, that is, to the meaning dimension of psychological empowerment. In the same line of argument, Cellar et al. (2011) and Payne et al. (2007) find a negative relationship between APGO and judgments of one's own competence. For high-APGO public employees, the possibility of failure after a performance evaluation could enhance the negative feelings of their empowerment.

In the Spanish local government context, employees have become used to a freedom and lack of accountability that allayed their fear of failure and insecurity about any possible poor judgment of their performance. With the latest performance-based reforms, such as the EBEP, this "bubble" of security has given way to a new situation of challenges and accountability for performance (Hall, 2017; Van Dooren et al., 2010), where employees with a high APGO disposition can find that they have less control over their tasks, or their 
activities become less meaningful. Therefore, high-APGO employees may perceive a more hostile environment that leads them to feel less psychologically empowered. Accordingly, we put forward the following hypothesis:

Hypothesis 1c. There is a negative relationship between APGO and psychological empowerment.

\section{Outcomes of Psychological Empowerment}

Job satisfaction. In the public administration literature, one of the most widely studied concepts is job satisfaction (Cantarelli, Belardinelli, \& Belle, 2016), which is defined as "the pleasurable emotional state resulting from the appraisal of one's job as achieving or facilitating the achievement of one's job values" (Locke, 1969, p. 316). On the basis of Spreitzer's psychological empowerment model, Spreitzer, Kizilos, and Nason (1997) found a positive link between psychological empowerment and work satisfaction. Moreover, Hackman and Oldham's (1976) job characteristics model proposes that three key psychological states (experienced responsibility for outcomes, experienced meaningfulness, and knowledge of the actual results) —which correspond to the meaning and impact dimensions of psychological empowerment-influence beneficial personal and work outcomes, such as job satisfaction, by encouraging feelings of personal growth and development with regard to the job. Many studies have explored these arguments further, finding the same positive relationship (e.g., Carless, 2004; Dewettinck \& Van Ameijde, 2011; Li, Kuo, Huang, Lo, \& Wang, 2013; Seibert, Silver, \& Randolph, 2004).

Empirical evidence of this relationship is not abundant in the public sector (Cho \& Faerman, 2010). Only the healthcare field has a relatively large number of studies (e.g., Li et al., 2013), one of the findings being that psychological empowerment is strongly and positively linked to nurses' work satisfaction. With regard to other public sector fields, as far 
as we know, very few studies have dealt with the link between psychological empowerment and job satisfaction (e.g., Carless, 2004; Harris, Wheeler \& Kacmar, 2009). Despite the current situation of stagnant wages, recruitment freezes, and increased working hours in Spanish local authorities, psychologically empowered employees in these organizations may also experience higher levels of job satisfaction since such feelings may promote personal growth and fulfillment at work. Positive cognitive evaluation of their current work situation-and thus their job satisfaction-will therefore be improved (Judge, Thoresen, Bono, \& Patton, 2001). This leads us to our next hypothesis:

Hypothesis 2a. There is a positive relationship between psychological empowerment and job satisfaction.

Affective commitment. Affective commitment denotes the "employee's emotional attachment to, identification with, and involvement in the organization" (Kim, 2005, p. 248). As in the case of job satisfaction, Hackman and Oldham's (1976) job characteristics model provides a suitable frame to understand this relationship. The three critical psychological states proposed in the model (corresponding to the meaning and impact dimensions of psychological empowerment) are the cause of positive outcomes in employees, since when they personally experience responsibility for a task, they experience positive affect. The norm of reciprocity (Cropanzano \& Mitchell, 2005) also supports this relationship (Dewettinck \& Van Ameijde, 2011). This norm refers to the socially accepted behavior of returning a favor when one is helped or provided with a resource (Cropanzano \& Mitchell, 2005). Employees are therefore inclined to be grateful and committed to organizations that make them feel responsible for their work, as well as having feelings of competence, impact, meaning, and self-determination (Liden, Wayne, \& Sparrowe, 2000).

Several studies have analyzed this relationship in the private sector (e.g., Dewettinck \& Van Ameijde, 2011; Macsinga et al., 2015). As in the case of job satisfaction, the 
healthcare services field has attracted the attention of organizational commitment scholars (e.g., Kraimer, Seibert, \& Liden, 1999). Positive and significant links have been found between psychological empowerment and affective commitment among nurses, and in other healthcare workplaces (e.g., dental services), although very little empirical research has been carried out in other public sector fields, not only on the psychological approach, but also on empowerment in general and its consequences (Fernandez \& Moldogaziev, 2011). However, the small number of extant studies, such as Chen and Chen's research (2008) in state-owned enterprises, also supports the positive link between psychological empowerment and organizational commitment. The conditions of Spanish local authority employees favor a high sense of belonging to their organization because of their long job tenure (Park \& Rainey, 2007; Torres et al., 2011). Thus, when they experience high levels of autonomy, competence, impact and meaning related to their job activities, their general affective commitment may be enhanced because their individual values will better fit with their work role. The above arguments lead to the following hypothesis:

Hypothesis $2 b$. There is a positive relationship between psychological empowerment and affective commitment.

Anxiety at Work. Anxiety refers to an emotional state of nervousness and increased agitation (Spector, Dwyer, \& Jex, 1988). Job anxiety, specifically, is a type of anxiety stimulated by the workplace (Muschalla, Linden, \& Olbrich, 2010). Empirical evidence deriving from studies of health service workers has shown the negative link between psychological empowerment and employees' variables related to job anxiety and general mental health, such as burnout or job strain (e.g., Hochwälder \& Brucefors, 2005; Laschinger, Finegan, Shamian, \& Wilk, 2001). Similar findings have been reported by other types of studies. In their meta-analytic study, Seibert et al. (2011) found that psychological empowerment is related to lower levels of strain. Likewise, Jensen, Patel, and Messersmith 
(2013) found that job control (which tallies with the self-determination and impact dimensions of psychological empowerment) contributes to reduce job anxiety levels in government employees. All these findings are consistent with Karasek's (1979) demandscontrol model, which states that perceived control over potential stressors, such as work decisions and tasks, and feelings of autonomy, allow people to cope better with job demands and reduce perceived strain. In the context of Spanish local authority employees, despite the recent measures to assess performance, and the challenging conditions that could undermine their hedonic well-being, it is expected that if they experience high levels of control over their job activities, perceive they have an impact on the results, are competent, and have autonomy to act, they will feel less tense, which could reduce their sense of fear, and thus, their job anxiety in general. The above empirical and theoretical arguments lead us to our final hypothesis:

Hypothesis 2c. There is a negative relationship between psychological empowerment and job anxiety.

Insert Figure 1 about here

\section{METHOD}

\section{Sample and Procedure}

In addition to drawing on previous studies (e.g., Barba \& Serrano, 2015; Rosa, Morote, \& Colomina, 2013), we also obtained the data to test the hypotheses from a sample of local authorities in Spanish towns with more than 20,000 inhabitants. We focused on large municipalities since they are able to implement more strategic management practices (Poister \& Streib, 2005), such as NPM and performance-based reforms. We identified these councils 
from the Federación Española de Municipios y Provincias (Spanish Federation of Municipalities and Provinces) database, which contains all Spanish city councils and their contact information.

As our unit of analysis was the employees, a questionnaire was prepared to assess their goal orientation, psychological empowerment, and attitudinal and health outcomes (job satisfaction, affective commitment, and job anxiety). The questionnaire was uploaded to an online survey application and was reviewed by two workers from different departments of four local governments (pretest through focus groups). Incorporating a qualitative method into the research design helps to mitigate the risk of bias (Forza, 2002; Groves et al., 2004). In the interviews, the respondents were asked to complete the questionnaire while one of the authors observed them. The researcher then asked about aspects such as the clarity and structure of the survey, and encouraged the respondents to express their ideas, suggest improvements, describe their feelings while completing the questions, and so on. We were able to verify that the respondents selected were suitably qualified to address our questions, and their feedback also helped to improve the survey. We were therefore able to corroborate that all the survey questions met content, cognitive, and usability standards (Groves et al., 2004). Having modified the questionnaire in line with the outcomes of the focus group, we began the data collection procedure. First, we contacted all the city councils in the population by telephone and identified the human resource managers, or the person in charge of personnel management (sometimes the clerk or auditor), in order to explain the study and request their email addresses. Emails were sent to these managers, asking them to explain the research to workers from different departments, by email, together with the questionnaire to gather their responses. A follow-up telephone call was made to increment response, as proposed in the literature (Dillman, Smyth, \& Christian, 2009). 
Only questionnaires from city councils in which at least four employees had answered the questionnaire were retained, following previous contributions (e.g., Seibert et al., 2004; Shen, 2016) in which samples consisted of several workers from different organizations. As a result, 553 questionnaires completed by public employees from 111 of the 399 local authorities in the population were finally used in our empirical research. At the organizational level, the 111 local authorities participating yielded a response rate of $27.82 \%$, with a sample error of $\pm 7.91 \%$ at the $5 \%$ significance level. The presence of non-response bias was tested with the commonly used time extrapolation test. We performed a $t$-test on the scores of the early and late respondents (Armstrong \& Overton, 1977). No significant differences $(p<.05)$ were detected in any of the main or control variables, confirming that absence of nonresponse bias in the study. The average number of employees per local authority was five ( $S D$ $=2.69$ ). The departments surveyed covered a wide range of local authority services, including human resource management, accounting, town planning, tourism, and social services. The participants reported an average of 17 years' experience in their organizations $(S D=9.63)$, and an average age of 47 years $(S D=7.62)$. They were predominantly women $(62.6 \%)$, and non-supervisors $(67.8 \%)$.

We confirmed the representativeness of the sample by investigating the current public employee profile in Spain and comparing it with our sample characteristics. We also took into account the situation of public management and the recent freeze on recruitment of new employees. The economic crisis has led to significant reductions in local government staff in the last years; specifically, in January 2010 there were 580,869 employees working in Spanish city councils, but by July 2016 this number had fallen to 486,962 (Staff Service of the Public Administrations Statistical Bulletin, July 2016). As a result, no vacancies are being filled and the workforce is gradually aging. Our sample profile therefore aligns with that of Spanish city council employees in terms of the aspects detailed above. The age, gender, and 
tenure profile of the participants is also very similar to that of other recent studies on Spanish public employees (e.g., González, Alaminos, \& Villar-Rubio, 2016), where a predominance of women and a relatively long job tenure are also appreciated.

Some procedural measures were used to minimize the risk of common method bias, as suggested by Podsakoff, MacKenzie, and Podsakoff (2012) and Brannick, Chan, Conway, Lance, and Spector (2010). First, we gave participants an appropriate cover story and instructions. Second, we labeled each part of the questionnaire by including titles for the variables of interest. Finally as noted earlier, we obtained data through online questionnaires rather than personal interviews. We also checked for common method bias by means of a statistical procedure frequently recommended in the literature - a single-factor test (Podsakoff, MacKenzie, \& Podsakoff, 2003) — to evaluate the existence of common method variance. The results of the CFA with all the items loading onto a single-factor (S-B $\chi^{2}=$ 6917.864, $d f=527 ; \mathrm{BB}-\mathrm{NNFI}=.165 ; \mathrm{CFI}=.216$; RMSEA $=.148)$ showed a poor fit, leading us to infer that common method bias does not give rise to concern in this study.

\section{Measures}

The appendix provides a detailed description of the measures used in our research. Because the scales were originally constructed in English, we applied standard translation and backtranslation procedures to translate the measures into Spanish.

Psychological Empowerment. Psychological empowerment was measured with Spreitzer's 12-item Psychological Empowerment Scale (1995). It consists of four subscales, one for each dimension of empowerment: meaning $(\alpha=.874)$, competence $(\alpha=.858)$, selfdetermination $(\alpha=.897)$, and impact $(\alpha=.940)$, each with three items. This is a 7-point Likert-type scale ranging from 1 (strongly disagree) to 7 (strongly agree). Collectively, the 12 items showed high reliability $(\alpha=.856)$. 
Goal Orientation. We used the Brett and VandeWalle (1999) scale, specific to work settings, to assess workers' levels of LGO (5 items, $\alpha=.861$ ), PPGO (4 items, $\alpha=.914$ ), and APGO (4 items, $\alpha=.809$ ). This is a 7-point Likert-type scale ranging from 1 (strongly disagree) to 7 (strongly agree).

Job Satisfaction. Job satisfaction was measured with Warr and Inceoglu's (2012) single-item 7-point Likert-type scale, where $1=$ extremely dissatisfied and $7=$ extremely satisfied. The single-item measure has been shown to correlate closely with multi-item scales (Wanous, Reichers, \& Hudy, 1997) and has frequently been used in previous studies (Cantarelli et al., 2016; Vermeeren et al., 2011).

Affective Commitment. We used the three items for affective commitment from Gellatly, Meyer, and Luchack's (2006) organizational commitment scale. These are answered on a 6-point Likert-type scale, from $1=$ strongly disagree to $6=$ strongly agree $(\alpha=.876)$.

Job Anxiety. Job anxiety was assessed with Jensen et al.'s (2013) 4-point Likert-type scale, where $1=$ not at all and $4=$ very much. The final five-item scale yielded $\alpha=.872$.

Controls. Guided by previous studies (e.g., Ang, Van Dyne, \& Begley, 2003; Boxall, Ang, \& Bartram, 2011; Ergeneli, Ari, \& Metin, 2007; Jensen et al., 2013; Koberg, Boss, Senjem, \& Goodman, 1999; Maynard et al., 2014; Park \& Rainey, 2007; Rusli, Edimansyah, \& Naing, 2008; Spreitzer et al., 1997), we controlled for organizational tenure (years working in the city council), job position (supervisor=1 or non-supervisor $=0$ ), gender $($ male $=0$ or female $=1$ ), and age (years).

\section{Analytic Strategy}

We applied structural equation modeling (SEM) to empirically validate the proposed model using the EQS 6.2 program (Bentler, 2006). The chi-square values shown correspond to Satorra and Bentler's (1994) scaled goodness-of-fit statistics, to prevent possible deviations from normality. Several fit indices are reported as well as the chi-square values, since the 
sample analyzed was large, and because the chi-statistic is sensitive to sample size (Hair, Black, Babin, \& Anderson, 2010).

The data presented a non-independent structure because the 553 employees were working in 111 city councils, and those employed by the same city council might share some common characteristics that could affect the results deriving from the responses. The city council was therefore used as a variable to nest the responses, implementing Satorra's (1992) correction for clustering.

\section{ANALYSIS AND RESULTS}

\section{Scale Validation}

Confirmatory factor analyses (CFA) were performed for each scale to examine the dimensionality of goal orientations (LGO, PPGO, and APGO), psychological empowerment, affective commitment, and job anxiety. First, a CFA was run to assess the fit of a four-factor model for the 12 items of psychological empowerment, providing a good fit (S-B $\chi^{2}=$ 106.926, $d f=48 ; \mathrm{BB}-\mathrm{NNFI}=.971 ; \mathrm{CFI}=.979 ; \mathrm{RMSEA}=.047)$. Then, a second-order factor CFA was estimated in which the first-order constructs of competence, meaning, selfdetermination, and impact were each loaded onto a single second-order latent construct representing psychological empowerment. The goodness-of-fit indices also revealed an adequate fit to the data for the higher-order model $\left(\mathrm{S}-\mathrm{B} \chi^{2}=141.266, d f=50\right.$; BB-NNFI $=.957 ; \mathrm{CFI}=.967 ; \mathrm{RMSEA}=.058)$, thus verifying that the model supports the higher-order factor structure of psychological empowerment.

Regarding GO, a CFA of the 13 items loading onto their corresponding factor (LGO, PPGO and APGO) indicated a good fit to the data for the three-factor model (S-B $\chi^{2}=$ $219.479, d f=62 ; \mathrm{BB}-\mathrm{NNFI}=.906 ; \mathrm{CFI}=.925 ; \mathrm{RMSEA}=.068)$, thereby supporting past findings (e.g., Brett \& VandeWalle, 1999; VandeWalle et al., 2001). 
As the CFA of job anxiety showed a poor fit, we removed one item loading below 0.5 , following recommendations in the literature (Bagozzi \& Yi, 1988; Hair et al., 2010). This change yielded acceptable fit values for the model $\left(\mathrm{S}-\mathrm{B} \chi^{2}=20.557, d f=5\right.$; BB-NNFI $=.930$; $\mathrm{CFI}=.965$; RMSEA $=.075)$. Finally, for affective commitment, a pooled measurement model of affective commitment and job anxiety was performed to avoid negative degrees of freedom, since it has only three indicators. This model also provided a good fit ( $\mathrm{S}-\mathrm{B} \chi^{2}=$ 66.904, $d f=19 ; \mathrm{BB}-\mathrm{NNFI}=.938 ; \mathrm{CFI}=.958 ; \mathrm{RMSEA}=.068)$.

In addition, a single measurement model was estimated to assess whether all the measures introduced in the structural model are distinct (Hair et al., 2010). To this end, a CFA was conducted where the three factors of GO, the second-order factor of psychological empowerment, job satisfaction, affective commitment and job anxiety correlate, and all items loaded on their respective factors. The output showed a good fit $\left(\mathrm{S}-\mathrm{B} \chi^{2}=1206.254, d f=501\right.$; BB-NNFI $=.941 ; \mathrm{CFI}=.947 ;$ RMSEA $=.05)$, and indicated that all items' factor loadings were significant $(p<0.01)$ and above the cutoff value.

Table 1 displays the means, standard deviations, and bivariate correlations among the estimated latent variables, following Maynard et al.'s (2014) presentation. Notably, the three dimensions of GO are significantly correlated with one another. Psychological empowerment is also highly correlated with LGO, and with PPGO, but no significant correlation was found with APGO. In turn, psychological empowerment also shows significant correlations with job satisfaction, affective commitment, and job anxiety. These findings provide partial preliminary support for the proposed relationships.

Insert Table 1 about here 


\section{Structural Model}

The findings from estimating the structural model are presented in Table 2 and Figure 2. The overall fit was acceptable, taking into account the value of the fit indices (S-B $\chi^{2}=1337.471$, $d f=623 ; \mathrm{BB}-\mathrm{NNFI}=.911 ; \mathrm{CFI}=.921 ; \mathrm{RMSEA}=.046)$.

GO as an Antecedent of Psychological Empowerment. In Hypothesis 1a, LGO was proposed as a predictor of psychological empowerment. The statistical values support this hypothesis $(\beta=.368, p<.001)$, showing that psychological empowerment is strongly driven by LGO. Hypothesis $1 \mathrm{~b}$ is not supported as there is no significant relationship between PPGO and psychological empowerment. Similarly, Hypothesis 1c is not confirmed as the relationship between APGO and psychological empowerment is not significant.

Outcomes of Psychological Empowerment. Hypothesis 2a was supported as more psychologically empowered employees feel more satisfied at work $(\beta=.485, p<.001)$. Similarly, consistent with Hypothesis 2b, feeling more psychological empowerment leads to greater attachment and commitment to the organization $(\beta=.729, p<.001)$. Finally, Hypothesis 2c was also confirmed, since job anxiety is significant and negatively predicted by psychological empowerment $(\beta=-.286, p<.001)$. Those who feel higher levels of psychological empowerment experience reduced levels of job anxiety ${ }^{1}$.

Insert Table 2 about here

\footnotetext{
${ }^{1}$ In response the comments of an anonymous reviewer, we estimated a new model that tested the relationships among the employee outcomes. Following previous literature, we introduced the link between satisfaction and commitment (e.g., Cantarelli et al., 2016; Dirani \& Kuchinke, 2011) and between anxiety and commitment (e.g., Bakker \& Demerouti, 2017). The findings did not support a significant relationship between either job satisfaction and commitment or anxiety and commitment, probably due to the strong psychological empowerment-commitment link.
} 
The indirect effects of learning goal orientation on outcome variables via psychological empowerment can also be reported by jointly taking into account the direct effects described above. The findings show an indirect effect of LGO through psychological empowerment for job satisfaction $(\beta=.178, p<.001)$, affective commitment $(\beta=.268, p$ $<.001)$, and job anxiety $(\beta=-.105, p<.01)$. No significant indirect effect was found in the case of either PPGO or APGO. Therefore, apart from the direct effects that psychological empowerment has on well-being, it also seems to channel LGO feelings into increased wellbeing.

Insert Figure 2 about here

\section{DISCUSSION}

This study extends research in the field of psychological empowerment, indicating a strong and significant relationship between LGO and psychological empowerment, and between psychological empowerment and the well-being outcomes of job satisfaction, affective commitment, and job anxiety, for a sample of Spanish local authority employees. The Spanish local government context is representative of traditional NPM ideals and the more recent performance-based reforms, with a growing concern to improve efficiency (Garcia, 2007; Ter Bogt, Van Helden, \& Van Der Kolk, 2015). At the same time, resistance to change from the latent 'administrative law culture' (Serna, 2008; Torres et al., 2011) and recent reforms, stagnant wages, frozen recruitment, and increased working hours introduced following the 2008 crisis, have all generated an hostile environment for employees (LópezAndreu, 2017). This workforce, mostly represented by civil servants who enjoy special status 
as a result of their long tenure (Torres et al., 2011), may perceive these circumstances as threatening, and experience detrimental feelings as a result. Our findings help to corroborate that if these employees feel psychologically empowered, their well-being will be enhanced, all of which can be brought about by high levels of LGO. Ultimately, this can improve service delivery and general performance in local authorities.

\section{Theoretical contributions}

The results shed light on the individual dispositions acting as drivers of psychological empowerment. We find support for the positive association between LGO and psychological empowerment, following past findings (e.g., Joo et al., 2016), and confirm this relationship for public employees. Therefore, employees with high LGO, who willingly seek opportunities to expand their abilities and knowledge and take risks to develop their work ability to better serve the public, are more likely to be highly motivated at work, to feel competent in performing their tasks, to enjoy autonomy and freedom to develop their work activities, and to make a contribution to their department, thus constituting a psychologically empowered workforce for these organizations.

We found no significant relationship for PPGO, possibly because in the public context, both traditional and revised GO perspectives arise and offset each other, leading to a null relationship. One possible explanation for this finding is that PPGO is not a "pure" form of regulation, in contrast to LGO and APGO (Elliot \& Church, 1997). Rather, it is an intricate construct driven by two different motivations: achievement and avoidance (Elliot \& Church, 1997). Therefore, when the achievement motivation is activated, individuals can feel and behave in a similar way and obtain comparable results to those with high LGO (Elliot, 1999). In contrast, when the avoidance motivation is activated, PPGO individuals may demonstrate a 
fear of challenge and dwell on negative information, similarly to those with high APGO (Li \& Bagger, 2008). It may be the case that the current mainstream tendency for individual performance evaluation in Spanish public organizations leads some high-PPGO employees to activate an achievement motivation, but given their special condition of indefinite tenure, perhaps other high-PPGO individuals may activate avoidance motivation and behave differently, since they might be resistant to pursuing performance aims (Serna, 2008). This mixed reality could lead to compensated effects that offset and cancel each other out.

APGO was not found to be negatively linked to psychological empowerment. A possible explanation for these findings could be that this goal orientation can be expressed as an active removal or a passive rumination of an unpleasant situation (Elliot \& Sheldon, 1998). As these authors argue, when APGO is manifested in active behavior to try and stop a negative situation, the outcomes are less detrimental and APGO is linked to specific approach-oriented sub-goals, so it may involve active and adequate forms of regulation (Elliot \& Sheldon, 1998). Perhaps public employees in the context studied do not tend to ruminate and act passively. Rather, since Spanish public sector employees generally enjoy the special status accorded by indefinite tenure (Torres et al., 2011), their most common behavior is to remove situations in which they fear they may not perform well by passing on those to colleagues or simply not doing them.

Furthermore, the confirmation of the hypotheses about psychological empowerment and its outcomes add to the growing body of research on the different psychological consequences they have for employees. The positive effect of psychological empowerment on job satisfaction has been reconfirmed (Carless, 2004; Harris et al., 2009; Spreitzer, 1995). The study clearly demonstrates that a high level of motivation at work, competence in work tasks, perception of self-regulation and autonomy to carry out daily activities, and feeling they are making a difference to the work unit through their own work, also help to enhance 
local authority employees' job satisfaction. In the same line, our results confirm the positive link between psychological empowerment and affective commitment found in previous studies (Dewettinck \& Van Ameijde, 2011; Macsinga et al., 2015), and lend support to the norm of reciprocity (Cropanzano \& Mitchell, 2005). If Spanish local authority employees feel psychologically empowered, they are more likely to have a solid sense of belonging to their city council, since the reciprocity of the relationship causes a feeling of gratitude to the organization. Both the effects on job satisfaction and on affective commitment found in this study allow us to confirm that eudaimonic well-being - namely, the fit between values and desires, and employees' work conditions - is achieved when they reach a psychologically empowered state of mind.

In addition, we have shown the importance of psychological empowerment in reducing levels of job anxiety. These findings provide interesting empirical support for the reaffirmation of psychological empowerment as a "protector" against ill health (Hochwälder \& Brucefors, 2005). In line with Karasek's (1979) demands-control model, our findings suggest that perception of one's influence on the way tasks are performed, which has an impact on the job, reduces levels of job anxiety in local authority employees. The study therefore confirms that a psychologically empowered state of mind contributes to hedonic well-being, since it leads to the avoidance of pain and induces a feeling of calm in these employees. Psychological empowerment therefore helps to improve both eudaimonic and hedonic employee well-being.

Finally, the analysis of the indirect effects reveals that employees' psychological empowerment also has the power to harness employees' disposition to learn, leading to wellbeing outcomes. Thus, when employees prefer work situations that require high ability and talent and are willing to select tasks in which they can learn, they experience higher job satisfaction and affective commitment and lower levels of anxiety at work because their 
feelings of empowerment are increased. Psychological empowerment emerges not only as a channel for well-being, but also as a central component in its generation (Amundsen \& Martinsen, 2015; Seibert et al., 2004).

\section{Practical contributions}

Some practical implications can be derived from our study. First, the results suggest the value of employees' motivations in consolidating a healthier and more committed staff. In this regard, staff selection systems should be improved to take into account employees' competences and attitudes (e.g., LGO) as far as the legal regulations governing public employee selection procedures allow. This is even more important in the case of public organizations than in the private sector, since public employees generally have indefinite tenure in the organization (Barba \& Serrano, 2015). For example, although the Spanish public administration applies several different selection systems, they mainly consist of written exams to test whether the candidate has the knowledge and skills necessary for the job. Interviews and psychological tests are sometimes used, but are not prioritized. Our results point to the advisability of incorporating tests on a more regular basis to evaluate employees' LGO as a complement to knowledge and skills requirements. Given the recent performancebased reforms (Van Dooren et al., 2010) and their emphasis on involving human resources in enhancing services provided to the public, more learning goal-oriented employees can help to guide this improvement process.

But can employees' LGO also be enhanced? Although LGO is a relatively stable personal disposition, it can also be influenced through external factors (Button, Mathieu, \& Zajac, 1996; Johnson, Shull, \& Wallace, 2011), indicating that techniques could be introduced to cultivate and sustain LGO in city council employees. In this line, it has been suggested that LGO can be induced by setting learning goals aimed at improving rather than demonstrating competencies, or creating an LGO climate that drives learning and 
development (Noordzij et al., 2013; Sanusi et al., 2007). To this end, training sessions could be used to raise employees' awareness and assess their learning goals (e.g., establishing a motto, explaining theory and providing examples of learning goals or balance sheets, practice in determining learning goals or completing balance sheets, feedback from trainer and colleagues, reinforcement exercises to do at home, discussions, etc.). Appraisal process functions might also be used to foster LGO. For instance, management by objectives and other contract-based employee assessment systems could offer local government managers suitable solutions, since it has been demonstrated that levels of competition, effort, and assessment standards can influence GO (Ames, 1992; Nicholls, 1984; Silver, Dwyer, \& Alford, 2006). Local government managers should consider these tools and encourage supervisors to model LGO and help to promote a continuous learning culture in the organization.

Secondly, and related to the above, the study highlights the key role of psychological empowerment and its power to generate favorable outcomes in public employees. As noted earlier, having satisfied and committed staff is fundamental in the paradigm of NPM and its more recent performance-based reforms (Gomes, Mendes, \& Carvalho, 2017; Perry, 2004). Therefore, the organizational outcomes derived from these positive employee attitudes are likely to be better than those from an uncommitted or dissatisfied staff. Furthermore, anxiety disorders and their detrimental effects are a problem in the private sector, but even more so in the public sector (McHugh, 1998). This can be an expensive problem for organizations if, for example, it leads to employees taking time off work due to sickness. Our findings suggest that local government managers should promote measures to take care of and improve psychological feelings of competence, meaning, impact, and self-determination among the workforce. Further still, this approach would enhance a more visible psychological 
empowerment culture, and public supervisors and employees in general should be helped to identify the feelings, attitudes, and behaviors related to the empowerment mindset.

\section{Limitations and future research}

The results of this study must be appraised in the light of its limitations. First, the sample for the study focuses on public-sector employees in Spanish local governments. Despite the important contribution our research makes to the psychological empowerment literature, future studies in other public settings are needed to generalize the model. Second, because the data were obtained at a single point in time, causality cannot be inferred. Future empirical studies could usefully adopt a longitudinal design to rigorously assess the causality in this hypothesized model. Although this research has expanded psychological empowerment theory and its relationships, more remains to be unraveled.

\section{REFERENCES}

Ames, C. (1992). Classrooms: Goals, Structures, and Student Motivation. Journal of Educational Psychology, 84(3), 261-271.

Amundsen, S., \& Martinsen, Ø. L. (2015). Linking empowering leadership to job satisfaction, work effort, and creativity: The role of self-leadership and psychological empowerment. Journal of Leadership \& Organizational Studies, 22(3), 304-323.

Ang, S., Van Dyne, L. \& Begley, T.M. (2003). The employment relationships of foreign workers versus local employees: A field study of organizational justice, job satisfaction, performance, and OCB. Journal of Organizational Behavior, 24(5), 561-583.

Armstrong, J. S., \& Overton, T. S. (1977). Estimating nonresponse bias in mail surveys. Journal of marketing research, 14, 396-402. 
Bagozzi, R. P., \& Yi, Y. (1988). On the evaluation of structural equation models. Journal of the Academy of Marketing Science, 16, 74-94.

Bakker, A. B., \& Demerouti, E. (2017). Job demands-resources theory: Taking stock and looking forward. Journal of Occupational Health Psychology, 22(3), 273.

Balaguer, M. T. (2004). 'La eficiencia en las administraciones locales ante diferentes especificaciones del output'. Hacienda Pública Española. Revista de Economía Pública, $170(3), 37-58$.

Barba, M. I., \& Serrano, J. (2015). ¿Es útil la gestión de los recursos humanos en los ayuntamientos? Is human resource management in local councils useful? Investigaciones Europeas de Dirección y Economía de la Empresa, 21, 9-16.

Barragán, M., \& Pérez, S. P. (2012). La experiencia del ayuntamiento de Castellón. Más poder local, (10), 44-46.

Barrick, M. R., Mount, M. K., \& Li, N. (2013). The theory of purposeful work behavior: The role of personality, higher-order goals, and job characteristics. Academy of management review, 38(1), 132-153.

Basic Statute of Public Employment, Act 7/2007, 12 April. Boletín Oficial del Estado, Spain,13 April 2007, 89, 16270-16299.

Bentler, P.M. (2006). EQS 6 Structural Equations Program Manual. Encino, California: Multivariate Software, Inc.

Boxall, P., Ang, S. H. and Bartram, T. (2011). 'Analysing the 'black box'of HRM: Uncovering HR goals, mediators, and outcomes in a standardized service environment'. Journal of Management Studies, 48:7, 1504-1532.

Brannick, M.T., Chan, D., Conway, J.M., Lance, C.E., \& Spector, P.E. (2010). What is method variance and how can we cope with it? A panel discussion. Organizational Research Methods, 13(3),407-420. 
Brett, J. F., \& VandeWalle, D. (1999). Goal Orientation and Goal Content as predictors of performance in a training program. Journal of Applied Psychology, 84(6), 863-873.

Brown, K. G. (2005). An examination of the structure and nomological network of trainee reactions: a closer look at" smile sheets. Journal of Applied Psychology, 90(5), 9911001.

Brunetto, Y., Shacklock, K., Bartram, T., Leggat, S. G., Farr-Wharton, R., Stanton, P., \& Casimir, G. (2012). Comparing the impact of leader-member exchange, psychological empowerment and affective commitment upon Australian public and private sector nurses: implications for retention. The International Journal of Human Resource Management, 23(11), 2238-2255.

Button, S. B., Mathieu, J. E., \& Zajac, D. M. (1996). Goal orientation in organizational research: A conceptual and empirical foundation. Organizational behavior and human decision processes, 67(1), 26-48.

Cantarelli, P., Belardinelli, P., \& Belle, N. (2016). A meta-analysis of job satisfaction correlates in the public administration literature. Review of Public Personnel Administration, 36(2), $115-144$.

Carless, S. A. (2004). Does Psychological Empowerment Mediate the Relationship Between Psychological Climate and Job Satisfaction? Journal of Business and Psychology, 18(4), $405-425$.

Cellar, D. F., Stuhlmacher, A. F., Young, S. K., Fisher, D. M., Adair, C. K., Haynes, S., Twichell, E., Arnold, K. A., Royer, K., Denning, B. L., \& Riester, D. (2011). Trait Goal Orientation, Self-Regulation, and Performance: A Meta-Analysis. Journal of Business and Psychology, 26(4), 467-483.

Chadwick, I. C., \& Raver, J. L. (2015). Motivating Organizations to Learn: Goal Orientation and Its Influence on Organizational Learning. Journal of Management, 41(3), 957-986. 
Chang, L. C., \& Liu, C. H. (2008). Employee empowerment, innovative behavior and job productivity of public health nurses: A cross-sectional questionnaire survey. International journal of nursing studies, 45(10), 1442-1448.

Chen, H. F., \& Chen, Y. C. (2008). The impact of work redesign and psychological empowerment on organizational commitment in a changing environment: An example from Taiwan's state-owned enterprises. Public Personnel Management, 37(3), 279-302.

Cho, T., \& Faerman, S. R. (2010). An Integrative Model of Empowerment and Individuals' InRole and Extra Role Performance in the Korean Public Sector: Moderating Effects of Organizational Individualism and Collectivism. International Public Management Journal, 13(2), 130-154.

Cropanzano, R., \& Mitchell, M. S. (2005). Social exchange theory: An interdisciplinary review. Journal of management, 31(6), 874-900.

Cuenca, J. (2010). Manual de Dirección y Gestión de Recursos Humanos en los Gobiernos Locales. Madrid -España: Instituto Nacional de Administración Pública. Publidisa S.A.

Dewettinck, K., \& Van Ameijde, M. (2011). Linking leadership empowerment behavior to employee attitudes and behavioral intentions. Testing the mediating role of psychological empowerment. Personnel Review, 40(3), 284-305.

Diefenbach, T. (2009). New public management in public sector organizations: the dark sides of managerialistic 'enlightenment'. Public administration, 87(4), 892-909.

Dietz, B., van Knippenberg, D., Hirst, G., \& Restubog, S. L. D. (2015). Outperforming whom? A multilevel study of performance-prove goal orientation, performance, and the moderating role of shared team identification. Journal of Applied Psychology, 100(6), 1811-1824.

Dillman, D.A., Smyth J.D., \& Christian L, (2009). Internet, Mail and Mixed-Mode Surveys: The Tailored Design Method. New Jersey: John Wiley \& Sons. 
Dirani, K. M., \& Kuchinke, K. P. (2011). Job satisfaction and organizational commitment: validating the Arabic satisfaction and commitment questionnaire (ASCQ), testing the correlations, and investigating the effects of demographic variables in the Lebanese banking sector. The International Journal of Human Resource Management, 22(05), $1180-1202$

Dweck, C. S. (1986). Motivational Processes Affecting Learning. American Psychologist, 41(10), 1040-1048.

Dweck, C. S., \& Leggett, E. L. (1988). A social-cognitive approach to motivation and personality. Psychological review, 95(2), 256-273.

Elliot, A. J. (1999). Approach and avoidance motivation and achievement goals. Educational psychologist, 34(3), 169-189.

Elliot, A. J., \& Church, M. A. (1997). A hierarchical model of approach and avoidance achievement motivation. Journal of Personality and Social Psychology, 72(1), 218-232.

Elliot, A. J., \& Harackiewicz, J. M. (1996). Approach and Avoidance Achievement goals and intrinsic motivation: a meditational analysis. Journal of Personality and Social Psychology, 70(3), 461-475.

Elliot, A.J., \& Moller, A. C. (2003). Performance-approach goals: good or bad forms of regulation? International Journal of Educational Research, 39(4-5), 339-356.

Ergeneli, A., Ari, G. S. I., \& Metin, S. (2007). Psychological empowerment and its relationship to trust in immediate managers. Journal of Business Research, 60(1), 41-49.

Feeney, M. K., \& DeHart-Davis, L. (2009). Bureaucracy and public employee behavior a case of local government. Review of Public Personnel Administration, 29(4), 311-326.

Fernandez, S., \& Moldogaziev, T. (2011). Empowering Public Sector Employees to Improve Performance: Does It Work? The American Review of Public Administration, 41(1), 2347. 
Fernandez, S., Resh, W. G., Moldogaziev, T., \& Oberfield, Z. W. (2015). Assessing the past and promise of the Federal Employee Viewpoint Survey for public management research: A research synthesis. Public Administration Review, 75(3), 382-394.

Forza, C. (2002). Survey research in operations management: a process-based perspective. International journal of operations \& production management, 22(2), 152194.

Gautam, D. K., \& Ghimire, S. B. (2017). Psychological Empowerment of Employees for Competitive Advantages: An Empirical Study of Nepalese Service Sector. International Journal of Law and Management, 59(4), 466-488.

Garcia, M.I. (2007). La nueva gestión pública: evolución y tendencias. Presupuesto y Gasto Público, 47, 37-64.

Gellatly, I. R., Meyer, J. P., \& Luchak, A. A. (2006). Combined effects of the three commitment components on focal and discretionary behaviors: A test of Meyer and Herscovitch's propositions. Journal of Vocational Behavior, 69, 331-345.

George, E., \& Zakkariya, K. A. (2014). Employees' perception of empowerment: a comparative study among different sectors of banks. International Journal of Services, Economics and Management 4, 6(2), 132-145.

Gomes, P., Mendes, S. M., \& Carvalho, J. (2017). Impact of PMS on organizational performance and moderating effects of context. International Journal of Productivity and Performance Management, 66(4), 517-538.

González, Pedro E., Alaminos, J., \& Villar-Rubio, E. (2016). Job Satisfaction among Public Employees Working Within Tax Administrations: Analyzing The Case of Spain. Regional and Sectoral Economic Studies 16(1): 17-32.

Groves, R. M., Fowler, F.J. Jr., Couper, M.P., Lepkowski, J.M., Singer, E. \& Tourangeau, R. (2004). Survey Methodology. John Wiley \& Sons. New Jersey. 
Hackman, J. R., \& Oldham, G. R. (1976). Motivation through the design of work: Test of a theory. Organizational behavior and human performance, 16(2), 250-279.

Hair, J. F., Black, W. C., Babin, B. J., \& Anderson, R. E. (2010). Multivariate data analysis. A global perspective (7th Eds.). NY: Pearson.

Hall, J. L. (2017). Performance Management: Confronting the Challenges for Local Government. Public Administration Quarterly, 41(1), 43-66.

Hansen, J. R., \& Høst, V. (2012). Understanding the relationships between decentralized organizational decision structure, job context, and job satisfaction-A survey of Danish public managers. Review of Public Personnel Administration, 32(3), 288-308.

Harackiewicz, J. M., Barron, K. E., Tauer, J. M., Carter, S. M., \& Elliot, A. J. (2000). Shortterm and long-term consequences of achievement goals: Predicting interest and performance over time. Journal of educational psychology, 92(2), 316-330.

Harris, K. J., Wheeler, A. R., \& Kacmar, K. M. (2009). Leader-member exchange and empowerment: Direct and interactive effects on job satisfaction, turnover intentions, and performance. Leadership Quarterly, 20(3), 371-382.

Hochwälder, J., \& Brucefors, A.B. (2005). Psychological empowerment at the workplace as a predictor of ill health. Personality and Individual Differences, 39(7), 1237-1248.

Jarman, L., Martin, A., Venn, A., Otahal, P., Taylor, R., Teale, B., \& Sanderson, K. (2014). Prevalence and correlates of psychological distress in a large and diverse public sector workforce: baseline results from Partnering Healthy@ Work.BMC public health, 14(1), $1-11$.

Jensen, J. M., Patel, P. C. \& Messersmith, J. G. (2013). High-Performance Work Systems and Job Control: Consequences for Anxiety, Role Overload, and Turnover Intentions. Journal of Management, 39(6), 1699-1724. 
Johnson, P. D., Shull, A., \& Wallace, J. C. (2011). Regulatory focus as a mediator in goal orientation and performance relationships. Journal of Organizational Behavior, 32(5), $751-766$.

Joo, B. K., Park, J. G., \& Lim, T. (2016). Structural determinants of psychological well-being for knowledge workers in South Korea. Personnel Review, 45(5), 1069-1086.

Judge, T. A., Thoresen, C. J., Bono, J. E., \& Patton, G. K. (2001). The job satisfaction-job performance relationship: A qualitative and quantitative review. Psychological Butlletin, 12(3), 376-407.

Karasek, R. A. (1979). Job demands, job decision latitude, and mental strain: Implications for job redesign. Administrative Science Quarterly, 24, 285-308.

Kim, P. B., Lee, G., \& Jang, J. (2017). Employee empowerment and its contextual determinants and outcome for service workers: A cross-national study. Management Decision, 55(5), $1022-1041$.

Kim, S. (2005). Individual-level factors and organizational performance in government organizations. Journal of public administration research and theory, 15(2), 245-261.

Koberg, C. S., Boss, R. W., Senjem, J. C., \& Goodman, E. A. (1999). Antecedents and outcomes of empowerment - Empirical evidence from the health care industry. Group \& Organization Management, 24(1), 71-91.

Kraimer, M. L., Seibert, S. E., \& Liden, R. C. (1999). Psychological empowerment as a multidimensional construct: A test of construct validity. Educational and Psychological measurement, 59(1), 127-142.

Laschinger, H. K. S., Finegan, J., Shamian, J., \& Wilk, P. (2001). Impact of structural and psychological empowerment on job strain in nursing work setting. The Journal of Nursing Administration, 31(5), 260-272. 
Lee, C., Tinsley, C., \& Bobko, P. (2003). Cross-cultural Variance in Goal Orientations and their Effects. Applied Psychology: An International Review, 52(2), 272-297.

Li, A., \& Bagger, J. (2008). Role ambiguity and self-efficacy: The moderating effects of goal orientation and procedural justice. Journal of Vocational Behavior, 73(3), 368-375.

Li, I. C., Kuo, H. T., Huang, H. C., Lo, H. L., \& Wang, H. C. (2013). The mediating effects of structural empowerment on job satisfaction for nurses in long-term care facilities. Journal of nursing management, 21(3), 440-448.

Liden, R. C., Wayne, S. J., \& Sparrowe, R. T. (2000). An examination of the mediating role of psychological empowerment on the relations between the job, interpersonal relationships, and work outcomes. Journal of Applied Psychology, 85(3), 407-416.

Locke, E. A. (1969). What is job satisfaction?. Organizational behavior and human performance, 4(4), 309-336.

López-Andreu, M. (2017). All precarious? Institutional change and turning points in labour market trajectories in Spain: Insights from narrative biographies. Employee Relations, $39(3), 408-422$.

Macsinga, I., Sulea, C., Sârbescu, P., Fischmann, G., \& Dumitru, C. (2015). Engaged, Committed and Helpful Employees: The Role of Psychological Empowerment. The Journal of Psychology, 149(3), 263-276.

Maynard, M. T., Gilson, L. L. \& Mathieu, J. E. (2012). Empowerment - Fad or Fab? A Multilevel Review of the Past Two Decades Research. Journal of Management, 38(4), $1231-1281$.

Maynard, M. T., Luciano, M. M., D’Innocenzo, L., Mathieu, J. E., \& Dean, M. D. (2014). Modeling time-lagged reciprocal psychological empowerment-performance relationships. Journal of Applied Psychology, 99(6), 1244-1253. 
McHugh, M. (1998). Rationalization as a key stressor for public sector employees: an organizational case study. Occupational medicine, 48(2), 103-112.

Middleton, M. J., Kaplan, A., \& Midgley, C. (2004). The change in middle school students' achievement goals in mathematics over time. Social Psychology of Education, 7(3), 289311.

Muschalla, B., Linden, M., \& Olbrich, D. (2010). The relationship between job-anxiety and trait-anxiety-A differential diagnostic investigation with the Job-Anxiety-Scale and the State-Trait-Anxiety-Inventory. Journal of anxiety disorders, 24(3), 366-371.

Nicholls, J. G. (1984). Achievement Motivation: Conception of Ability, Subjective Experience, Task Choice, and Performance. Psychological Review, 91(3), 328-346.

Nicholson-Crotty, S., Nicholson-Crotty, J., \& Fernandez, S. (2017). Performance and management in the public sector: Testing a model of relative risk aversion. Public Administration Review, 77(4), 603-614.

Noordzij, G., Hooft, E. A., Mierlo, H., Dam, A., \& Born, M. P. (2013). The effects of a learning-goal orientation training on self-regulation: A field experiment among unemployed job seekers. Personnel Psychology, 66(3), 723-755.

Onesti, T., Angiola, N., \& Bianchi, P. (2016). Learning by Using Performance Measures in Local Governments: The Perspective of Public Managers. Public Administration Quarterly, 40(4), 842.

Park, R. M., \& Rainey, H. G. (2007). Antecedents, Mediators, and Consequences of Affective, Normative, and Continuance Commitment. Empirical Tests of Commitment Effects in Federal Agencies. Review of Public Personnel Administration, 27(3), 197-226.

Payne, S. C., Youngcourt, S. S., \& Beaubien, J. M. (2007). A Meta-Analytic Examination of the Goal Orientation Nomological Net. Journal of Applied Psychology, 92(1), 128-150. 
Perry, R. W. (2004). The Relationship of Affective Organizational Commitment with Supervisory Trust. Review of Public Personnel Administration, 24(2), 133-149.

Petter, J., Byrnes, P., Choi, D. L., Fegan, F., \& Miller, R. (2002). Dimensions and patterns in employee empowerment: Assessing what matters to street-level bureaucrats. Journal of Public Administration Research and Theory, 12(3), 377-400.

Phan, H. P. (2009). Relations between goals, self-efficacy, critical thinking and deep processing strategies: a path analysis. Educational Psychology, 29(7), 777-799.

Pintrich, P. R. (2000). Multiple goals, multiple pathways: The role of goal orientation in learning and achievement. Journal of Educational Psychology, 92(3), 544-555.

Pitts, D. W. (2005). Leadership, Empowerment, and Public Organizations. Review of Public Personnel Administration, 25(1), 5-28.

Podsakoff, P.M., Mackenzie, S.B., Lee, J.Y., \& Podsakoff, N.P. (2003). Common method biases in behavioral research: a critical review of the literature and recommended remedies. Journal of Applied Psychology, 88(5), 879-903.

Podsakoff, P.M., MacKenzie, S.B., \& Podsakoff, N.P. (2012). Sources of method bias in social science research and recommendations on how to control it. Annual Review of Psychology, 63, 539-569.

Poister, T. H. \& Streib, G. (2005). Elements of Strategic Planning and Management in Municipal Government: Status after two Decades. Public Administration Review, 65(1), 45-56.

Rosa, C. P., Morote, R. P., \& Colomina, C. I. M. (2013). Performance Improvement in the Spanish Local Government: A Proposal for Internal Control in Social Care Services. International Business Research, 6(4), 10-24.

Rusk, N., \& Rothbaum, F. (2010). From stress to learning: Attachment theory meets goal orientation theory. Review of General Psychology, 14(1), 31-43. 
Rusli, B. N., Edimansyah, B. A., \& Naing, L. (2008). Working conditions, self-perceived stress, anxiety, depression and quality of life: a structural equation modelling approach. $B M C$ public health, $8(1), 48$.

Ryan, R.M., \& Deci, E.L. (2001). On happiness and human potentials: A review of research on hedonic and eudaimonic well-being. Annual review of psychology, 52(1), 141-166.

Sanusi, Z. M., Iskandar, T. M., \& Poon, J. M. (2007). Effects of Goal Orientation and Task Complexity on Audit Judgment Performance. Malaysian Accounting Review, 6(2).

Satorra, A. (1992). Asymptotic robust inferences in the analysis of mean and covariance structures. Sociological Methodology, 22, 249-278.

Satorra, A., \& Bentler, P.M. (1994). Corrections to test statistics and standard errors in covariance structure analysis. In A. von Eye \& C. C. Clogg (Eds.), Latent variables analysis: Applications for developmental research (pp. 399-419). Thousand Oaks, CA: Sage.

Scotti, D.J., Harmon, J., \& Behson, S.J. (2007). Links among High-Performance Work Environment, Service Quality and Customer Satisfaction: An Extension to the Healthcare Sector. Journal of Healthcare Management, 52(2), 109-125.

Seibert, S. E., Silver, S. R., \& Randolph, W. A. (2004). Taking Empowerment to the Next Level: a Multiple-Level Model of Empowerment, Performance, and Satisfaction. Academy of Management Journal, 47(3), 332-349.

Seibert, S. E., Wang, G., \& Courtright, S. H. (2011). Antecedents and Consequences of Psychological and Team Empowerment in Organizations: A Meta-Analytic Review. Journal of Applied Psychology, 96(5), 981-1003.

Serna, M.S. (2008). Nuevas tendencias en gestión de recursos humanos en las Administraciones públicas:¿están cambiando las reglas del juego? Revista internacional de organizaciones, 1,109-127. 
Shen, J. (2016). Principles and applications of multilevel modeling in human resource management research. Human Resource Management, 55(6), 951-965.

Silver, L. S., Dwyer, S., \& Alford, B. (2006). Learning and performance goal orientation of salespeople revisited: The role of performance-approach and performance-avoidance orientations. Journal of Personal Selling \& Sales Management, 26(1), 27-38.

Smith, L., Andrusyszyn, M. A., \& Laschinger, H. K. (2010). Effects of workplace incivility and empowerment on newly-graduated nurses' organizational commitment. Journal of nursing management, 18(8), 1004-1015.

Spector, P. E., Dwyer, D. J., \& Jex, S. M. (1988). Relation of job stressors to affective, health, and performance outcomes: a comparison of multiple data sources. Journal of Applied Psychology, 73(1), 11-19.

Spreitzer, G. M. (1995). Psychological empowerment in the workplace: dimensions, measurement, and validation. Academy of Management Journal, 38(5), 1442-1465.

Spreitzer, G. M., Kizilos, M. A., \& Nason, S. W. (1997). A dimensional analysis of the relationship between psychological empowerment and effectiveness, satisfaction, and strain. Journal of Management, 23(5), 679-704.

Statistical Gazette of the Staff at the Service of Public Administrations, July 2016. Ministerio de Hacienda y Administraciones Públicas.

Steijn, B. (2004). Human resource management and job satisfaction in the Dutch public sector. Review of Public Personnel Administration, 24(4), 291-303.

Taylor, J. (2013). Goal setting in the Australian public service: Effects on psychological empowerment and organizational citizenship behavior. Public Administration Review, 73(3), 453-464. 
Ter Bogt, H. J., Van Helden, G. J., \& Van Der Kolk, B. (2015). Challenging the NPM Ideas about Performance Management: Selectivity and Differentiation in Outcome-Oriented Performance Budgeting. Financial Accountability \& Management, 31(3), 287-315.

Thomas, K.W., \& Velthouse, B. A. (1990). Cognitive Elements of Empowerment - an Interpretive Model of Intrinsic Task Motivation. Academy of Management Review, 15(4), 666-681.

To, M. L., Fisher, C. D., \& Ashkanasy, N. M. (2015). Unleashing angst: Negative mood, learning goal orientation, psychological empowerment and creative behaviour. Human relations, 68(10), 1601-1622.

Torres, L., Pina, V., \& Yetano, A. (2011). Performance measurement in Spanish local governments. A cross-case comparison study. Public administration, 89(3), 1081-1109.

Van De Voorde, K., Paauwe, J., \& Van Veldhoven, M. (2012). Employee well-being and the HRM-organizational performance relationship: a review of quantitative studies. International Journal of Management Reviews, 14(4), 391-407.

Van Dooren, W., Bouckaert, G., \& Halligan, J. (2010). Performance management in the public sector. Routledge.

Van Loon, N. M. (2017). Does context matter for the type of performance-related behavior of public service motivated employees? Review of public personnel administration, 37(4), $405-429$.

VandeWalle, D. (1997). Development and Validation of a work domain goal orientation instrument. Educational and Psychological Measurement, 57(6), 995-1015.

VandeWalle, D., Cron, W. L., \& Slocum Jr, J. W. (2001). The role of goal orientation following performance feedback. Journal of Applied Psychology, 86(4), 629-640. 
Vermeeren, B., Kuipers, B., \& Steijn, B. (2011). Two faces of the satisfaction mirror: a study of work environment, job satisfaction, and customer satisfaction in Dutch municipalities. Review of public personnel administration, 31(2), 171-189.

Wanous, J. P., Reichers, A. E., \& Hudy, M. J. (1997). Overall job satisfaction: how good are single-item measures? Journal of applied Psychology, 82(2), 247-252.

Warr, P., \& Inceoglu, I. (2012). Job Engagement, Job Satisfaction, and Contrasting Associations With Person-Job Fit. Journal of Occupational Health Psychology, 17(2), 129-138.

Whetten, D.A. (1989). What constitutes a theoretical contribution? Academy of Management Review, 14(4), 490-495.

Wieclaw, J., Agerbo, E., Mortensen, P. B., Burr, H., Tuchsen, F., \& Bonde, J. P. (2008). Psychosocial working conditions and the risk of depression and anxiety disorders in the Danish workforce. BMC Public Health, 8(1), 280.

Winters, D., \& Latham, G. P. (1996). The effect of learning versus outcome goals on a simple versus a complex task. Group \& Organization Management, 21(2), 236-250.

Wolters, C, Yu, S., \& Pintrich, P. R. (1996). The relation between goal orientation and students' motivational beliefs and self-regulated learning. Learning and Individual Differences, 8 , 211-238. 


\section{Appendix}

\section{Scales}

\section{PSYCHOLOGICAL EMPOWERMENT}

\section{Meaning}

1- The work I do is very important to me.

2- My job activities are personally meaningful to me.

3- The work I do is meaningful to me.

\section{Competence}

4- I am confident about my ability to do my job.

5- I am self-assured about my capabilities to perform my work activities.

6- I have mastered the skills necessary for my job.

\section{Self-determination}

7- I have significant autonomy in determining how I do my job.

8- I can decide on my own how to go about doing my work.

9- I have considerable opportunity for independence and freedom in how I do my job.

\section{Impact}

10- My impact on what happens in my department is large.

11- I have a great deal of control over what happens in my department.

12- I have significant influence over what happens in my department. 


\section{GOAL ORIENTATIONS}

\section{Learning goal orientation}

1- I am willing to select a challenging work assignment that I can learn a lot from.

2- I often look for opportunities to develop new skills and knowledge.

3- I enjoy challenging and difficult tasks at work where I'll learn new skills.

4- For me, development of my work ability is important enough to take risks.

5- I prefer to work in situations that require a high level of ability and talent.

\section{Prove-performance goal orientation}

6- I like to show that I can perform better than my coworkers.

7- I try to figure out what it takes to prove my ability to others at work

8- I enjoy it when others at work are aware of how well I am doing.

9- I prefer to work on projects where I can prove my ability to others.

\section{Avoid-performance goal orientation}

10- I would avoid taking on a new task of there was a chance that I would appear rather incompetent to others.

11- Avoiding a show of low ability is more important to me than learning a new skill.

12- I'm concerned about taking on a task at work if my performance would reveal that I had low ability.

13- I prefer to avoid situations at work where I might perform poorly.

\section{JOB SATISFACTION}

In general, how do you feel about your work? Please select only one of the following options:

$\square$ Extremely dissatisfied

$\square$ Mostly dissatisfied

$\square$ Slightly dissatisfied

$\square$ Indifferent

$\square$ Slightly satisfied

$\square$ Mostly satisfied

$\square$ Extremely satisfied

\section{AFFECTIVE COMMITMENT}

1- This organization has a great deal of personal meaning for me.

2- I feel a strong sense of "belonging" to my organization.

3- I feel like "part of the family" in this organization. 


\section{JOB ANXIETY}

1- I feel tense or wound up.

2- I get a sort of frightened feeling like "butterflies" in the stomach.

3- I get a sort of frightened feeling as if something awful is about to happen.

4- I feel restless as if I have to be on the move.

5- I get sudden feelings of panic.

6- I can sit at ease and feel relaxed* $(\mathrm{R})$

Notes: (R), inverse indicator; *, eliminated indicator 